\title{
Editorial to volume 72 issue 1
}

\section{Anandaraj ${ }^{1,2}$}

(c) Indian Phytopathological Society 2019

Dear Readers,

One year has passed since Springer-Nature joined hands with Indian Phytopathological Society in publishing the Indian Phytopathology Journal. As expected, the changes are quite obvious. The circulation has been impressive with 4433 downloads; 2250 by the society members and 2183 globally. The first issue of volume 72:1 (March 2019) of Indian Phytopathology has been published before March 2019. In this issue, there are twenty articles including one review, fifteen research articles and three short communications and a first report. The review is J. F. Dastur Memorial Lecture Award on "Present status and future research dimensions of soybean diseases for sustainable productivity of soybean in India" by Dr. Shamarao Jahagirdar. He has highlighted the current status of research on soybean rust. There are five articles on cereals; three on rice and one each on wheat and sorghum. There are four articles on vegetable crops; followed by pulses one each on soybean and mung bean. The major focus was on screening as there are six articles on locating resistance, identifying races and field screening. Pathogen groups covered are; oomycetes, powdery mildew, Macrophomina, Phomopsis, Rhizoctonia and plant parasitic nematode Meloidogyne incognita. Integrated management has been focused in most of the disease management strategy.

The editorial team, the executive committee and business manager have put in lot of efforts to bring this publication. There were 339 manuscript received by the society out of which 69 were accepted, 74 rejected and the remaining in various stages of processing.

I earnestly hope that the authors would send the best results to Indian pathology and cooperate with the editorial team to maintain the high standards of Indian Phytopathology. I express my sincere thanks to the authors, reviewers, editorial team, the executive of Indian Phytopathological Society and business manager for all their help.

Dr. M. Anandaraj

Chief Editor

Publisher's Note Springer Nature remains neutral with regard to jurisdictional claims in published maps and institutional affiliations.
M. Anandaraj

arajiisr@gmail.com

Indian Phytopathological Society, New Delhi, India

2 Bangalore, India 